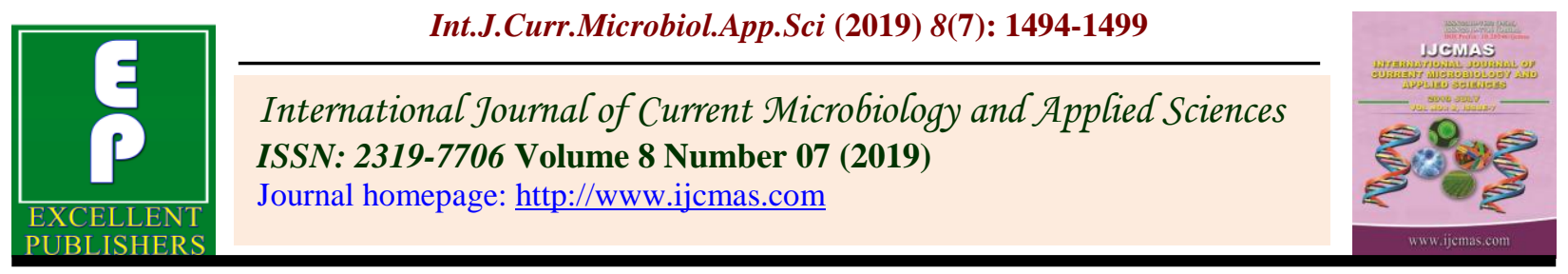

Original Research Article

https://doi.org/10.20546/ijcmas.2019.807.177

\title{
Gap in Adoption of Improved Production Technology of Gram among the Farmers of Rehli Block of Bundelkhand Region
}

\author{
Vikas Gupta*, S.K. Mishra, R.K. Saraf and Akhilesh Tiwari
}
Jawaharlal Nehru Krishi Vishwa Vidyalaya, Dryland Horticulture Research \& Training Centre, Garhakota, District-Sagar (M.P.), India

*Corresponding author

\begin{tabular}{|l|}
\hline Ke y w o r d s \\
$\begin{array}{l}\text { Chickpea, } \\
\text { Knowledge, } \\
\text { Adoption gap, } \\
\text { reasons }\end{array}$ \\
\hline Article Info \\
\hline $\begin{array}{l}\text { Accepted: } \\
\text { 12 June } 2019 \\
\text { Available Online: } \\
\text { 10 July } 2019\end{array}$ \\
\hline
\end{tabular}

A B S T R A C T

The present study was undertaken during Krishi Mahotsav programme to find out the reasons for less adoption of improved gram production technology among the farmers of Rehli block of bundelkhand region during the year 2014 and 2015. It is found that majority of the respondents $(59.90 \%)$ had medium level of adoption, followed by those having low $(24.56 \%)$ and high $(15.54 \%)$ levels of adoption for the improved practices of chickpea cultivation. Results revealed that there were number of reasons for low adoption of improved chikpea production technology. Some were most important such as, less availability of seed of improved high yielding variety, problem of wilt disease, problem of pod borer, improper method of sowing, lack of soil testing based fertilizer application, lack of integrated weed management, lack of integrated pest management, losses during seed storage.

\section{Introduction}

Pulses, once referred to as the poor man's meat are becoming increasingly important in crop production systems. They fix atmospheric nitrogen. The per capita availability of pulses progressively declined from $70 \mathrm{~g}$ in 1956 to $44 \mathrm{~g}$ in 2015-16 against the recommended requirement of 80g/day/capita (Anonymous 2016). Inclusion of legume in a particular cropping system improves the soil health depending upon its duration, fertilization, nature and purpose for which that is grown. Chickpea (Cicer arietinum L.) is the most important rabi pulse crop of India under rainfed and limited irrigation conditions. In India, it accounts for more than one third of the area and about 50 per cent of the production of pulses. India accounts for about 65 per cent of the world acreage and 67 per cent production of chickpea at present. In India, it is grown over an area of 8.3 million hectares with productivity of $843 \mathrm{~kg} \mathrm{ha}-1$ and production of 
about 7.0 million tons (2014-15). Madhya Pradesh stands first position in production of chickpea in the country. Morena, Bhind, sheopurkala, Gwalior, Mandsaur are main chickpea growing districts in Madhya Pradesh. Its high nutritive value can be judged by the fact that it contains 20 per cent protein, 5 per cent fats and 55 per cent carbohydrates. It is also rich in calcium, iron and niacin. Therefore, it is an inexpensive, high-quality source of protein. It is not only an important source of protein in human diets, but it also plays a significant role in maintaining soil fertility, through biological nitrogen fixation. Average chickpea yield in India is very low compared with developed countries of the world. The average productivity of chickpea crop is quite low due to a number of abiotic and biotic stresses, e.g. non-adoption of improved technology and cultivation in marginal lands having low fertility.

The technology adoption by the farmers is an essential pre-requisite for economic prosperity in developing country likes India. Adoption may be defined as the integration of an innovation in to farmers' normal farming activities over an extended period of time (Feder et al., 1985). Increasing population pressures, traditional farming systems and small farm holding are not enough to support growing number of people in household. Whereas, the one who adopts improved crop production packages can produce ample food for as many as thousands of people. Successful adoption of improved agricultural technologies could stimulate overall economic growth through inter sectoral linkages while conserving natural resources (Sanchez et al., 2009). Past studies (Dixon et al., 2006; Wanyama et al., 2010) showed that adoption of improved production practices may help the farmers to get higher amount of yield and had impact on household food security and income. Adoption of agricultural technologies differs from farmer to farmer. Adoption refers to both mental acceptance and also covers the use of new agricultural technologies. In present study adoption is define as the use of recommended agricultural technologies on continuing basis. The new technology in general has been adopted by big farmers who were innovative and were well off in resource structures and inputs availability, resulted into wide range gap in term of adoption of chickpea production technology by big and small farmers. Rural development can be promoted through stimulating the adoption of improved production practices. Keeping this point of view, the study was undertaken with the objective to find out the reasons for gap in adoption of improved chickpea production practices by the farmers of Rehli block of bundelkhand region of Madhya Pradesh.

\section{Materials and Methods}

The study was conducted in the forty villages of Rehli block of Sagar district in Bundelkhand region of Madhya Pradesh during the year 2014 and 2015 under Krishi Mahotsav programme organized by Department of Farmer Welfare and Agriculture Development, Sagar (M.P.). Out of all the total farm family, five farmers were selected as respondents from each village. In this way a total 200 farmers were selected from whole selected villages for collection of data. The field data along with other required information were collected through prestructure interview schedules by personal interview/method, where farmers were asked to give the account of package of practices they followed in chickpea. The adoption level was estimated in term of acceptance of technology by respondents as given by Singh et $a l$., in 2014. The adoption was categorized into three levels viz., full, partial and nonadoption and these were assigned the score 2, 1 and 0 , respectively. The total score of all categories was considered as adoption score of individual. 


\section{Results and Discussion}

\section{Adoption level of farmers regarding improved practices of chickpea cultivation}

Data presented in Table 1 revealed that majority of the respondents $(53.88 \%)$ had medium level of adoption, followed by those having low (27.22\%) and high (18.88\%) levels of adoption about improved practices of chickpea cultivation.

\section{Reasons for low adoption of improved chickpea technology}

The reasons responsible for low adoption of recommended and improved practices of chickpea cultivation as reported by farmers were presented in Table 2.

\section{Less use of high yielding variety}

High Yielding Variety plays a vital role in good vegetative and reproductive growth and yield of chickpea crop. Less availability of seed of high yielding variety is one of the most important constraints for poor yield of the farmers. The data depicted from the data of Table 2 that 'unavailability of seed of new high yielding variety (HYV) in time' (71.00\%), 'high cost of HYV seed'(65.50\%) and 'Lack of knowledge about high yielding varieties' $(55.50 \%)$ were the important reasons responsible for less availability of seed of high yielding variety.

\section{Improper method of sowing}

Method of sowing is very much affected the germination of seed, seedling growth, plant population etc. which ultimately badly affect the yield of crop. Method of sowing is influenced by the number of factors like lack of knowledge about proper method of sowing, mixing of DAP with seed, use of high seed rate, use of own seed without grading, germination test etc. It is obvious from the data that mixing of DAP with seed (94\%) is the main type of improper method of sowing. 'Lack of knowledge about proper method of sowing' $(89 \%)$ is the most important reason for the adoption of improper method of sowing by the farmers. Use of high seed rate $(76.50 \%)$ and use of own seed without grading, germination test $(37 \%)$ are the other types of improper method of sowing (Table 2).

\section{Lack of seed treatment}

Seed treatment is a very important package of practice because it not only save the seed from different insect pest and diseases (use of thiometoxam, Trichoderma viridae), reduce the additional need of nutrients (use of PSB, Azotobacter, Azospirillum etc.) but also augment the yield by $10-15 \%$ and reduce the need of nutrients. Shahid et al., (2011) and Chormule et al., (2015) also highlighted the importance of seed treatment in chickpea crop. It is found that 'Lack of knowledge about importance of seed treatment' $(65.00 \%)$ is the main reason for less adoption of seed treatment practices followed by 'unavailability of seed dresser' $(56.50 \%)$ and 'high cost of chemicals' $(22.50 \%)$.

\section{Fertilizer application without soil test}

Inspite of many government and nongovernment efforts still most of the farmers applying fertilizers in their fields without prior soil test. Due to that appropriate doze of nutrients cannot reaches in the field which adversely affect the productivity and fertility of soil. It is apparent from the data of Table 2 that 'lack of knowledge about soil sampling method for soil test' $(89.00 \%)$ is the main reason responsible for low adoption of fertilizer application without soil test followed by lack of knowledge about importance of soil sampling $(79.50 \%)$ and 'Lack of soil testing laboratories near the villages' $(76.00 \%)$. 
Table.1 Distribution of respondents according to their level of adoption regarding improved chickpea cultivation

$(\mathrm{N}=200)$

\begin{tabular}{|l|l|c|c|}
\hline S. No. & Categories of adoption & No. of respondents & $\begin{array}{c}\text { Percentage of } \\
\text { adoption level }\end{array}$ \\
\hline $\mathbf{1}$ & Low & 49 & 27.22 \\
\hline $\mathbf{2}$ & Medium & 97 & 53.88 \\
\hline $\mathbf{3}$ & High & 34 & 18.88 \\
\hline & Total & $\mathbf{1 8 0}$ & $\mathbf{1 0 0 . 0 0}$ \\
\hline
\end{tabular}

Table.2 Major reasons for gap in adoption of improved chickpea production technology

$(\mathrm{N}=200)$

\begin{tabular}{|c|c|c|c|}
\hline S. No. & Reasons for less adoption of Improved Technology & No. of respondents & Percentage \\
\hline \multicolumn{4}{|c|}{ (A) Less Availability of Seed of High Yielding Variety } \\
\hline 1 & Lack of knowledge about High Yielding Varieties(HYVs) & 111 & 55.50 \\
\hline 2 & Unavailability of seed of new HYV in time & 142 & 71 \\
\hline 3 & High cost of seed of HYV & 131 & 65.50 \\
\hline (B) & \multicolumn{3}{|l|}{ Improper Method of Sowing } \\
\hline 1 & Lack of knowledge about proper method of sowing & 178 & 89 \\
\hline 2 & Use of high seed rate & 153 & 76.50 \\
\hline 3 & Use of own seed without grading, germination test & 74 & 37 \\
\hline 4 & Mixing of DAP with seed & 188 & 94 \\
\hline \multicolumn{4}{|c|}{ (C) Lack of Seed Treatment } \\
\hline 1 & Lack of knowledge about importance of seed treatment & 130 & 65.00 \\
\hline 2 & Unavailability of seed dresser & 113 & 56.50 \\
\hline 3 & High cost of chemicals & 45 & 22.50 \\
\hline \multicolumn{4}{|c|}{ (D) Fertilizer Application without Soil Test } \\
\hline 1 & Lack of knowledge about importance of soil testing & 159 & 79.50 \\
\hline 2 & Lack of knowledge about soil sampling method & 178 & 89.00 \\
\hline 3 & Lack of soil testing laboratories near the villages & 152 & 76.00 \\
\hline \multicolumn{4}{|c|}{ (E) Improper Method of Fertilizer Application } \\
\hline 1 & Lack of knowledge about fertilizers & 179 & 89.50 \\
\hline 2 & Improper method of DAP fertilizer application in field & 184 & 94.00 \\
\hline 3 & High cost of chemicals & 69 & 34.50 \\
\hline \multicolumn{4}{|c|}{ (F) Lack of Adoption of Integrated Weed Management } \\
\hline 1 & Lack of knowledge about weed identification & 111 & 56.00 \\
\hline 2 & Lack of knowledge about importance of cultural, physical and chemical methods & 157 & 78.50 \\
\hline 3 & Lack of knowledge about proper method of herbicide application & 59 & 29.50 \\
\hline 4 & Lack of knowledge about Integrated Weed Management & 177 & 88.50 \\
\hline 5 & Unavailability of herbicide in time & 69 & 34.50 \\
\hline 6 & High cost of herbicide & 32 & 16.00 \\
\hline (G) & \multicolumn{3}{|l|}{ Problem of Wilt Disease } \\
\hline 1 & Lack of knowledge about disease identification & 72 & 36.00 \\
\hline 2 & Lack of knowledge about different control methods & 162 & 81.00 \\
\hline 3 & Unavailability of Resistant Variety & 156 & 78.00 \\
\hline 4 & Lack of Seed Treatment for disease control & 133 & 66.50 \\
\hline 5 & Lack of Crop Rotation Practice for disease control & 154 & 77.00 \\
\hline 6 & Unavailability of chemicals & 93 & 46.50 \\
\hline (H) & \multicolumn{3}{|l|}{ Problem of Pod Borer Control } \\
\hline 1 & Lack of knowledge about insect attack & 79 & 39.50 \\
\hline 2 & Lack of knowledge about selection of proper insecticide, its dose to control insect at different stages & 178 & 89.00 \\
\hline 3 & Unavailability of appropriate insecticide at right time & 85 & 42.50 \\
\hline 4 & High cost of Insecticides & 74 & 37.00 \\
\hline \multicolumn{4}{|c|}{ (I) Lack of Adoption of Integrated Pest Management (IPM) } \\
\hline 1 & Lack of knowledge about importance of IPM & 149 & 74.50 \\
\hline 2 & Non availability of chemicals, plant protection equipments & 91 & 45.50 \\
\hline 3 & High cost of pesticide \& fungicides & 118 & 59.00 \\
\hline \multicolumn{4}{|c|}{ (J) Seed Losses During Storage } \\
\hline 1 & Lack of knowledge about importance of proper storage and its methods & 167 & 83.50 \\
\hline 2 & Lack of proper sun drying of seed & 136 & 68.00 \\
\hline 3 & Use of traditional storage practices & 73 & 36.50 \\
\hline 4 & Use of old jute bags for seed storage without cleaning, chemical treatment, sun drying etc. & 136 & 68.00 \\
\hline 5 & Unavailability of fumigants & 110 & 55.00 \\
\hline 6 & Lack of proper storage facility & 117 & 58.50 \\
\hline
\end{tabular}




\section{Improper method of fertilizer application}

94\% respondents during study informed that they use DAP along with seed in the seed drill during sowing of the crop. That is not only rotten the seed during its germination but also reduce the plant population. So, it is the main type of improper method of fertilizer application in field. Lack of knowledge about fertilizers and their use' $(89.50 \%)$ was the main reason for improper method of fertilizer application followed by 'High cost of chemicals' (34.50\%).

\section{Lack of adoption of integrated weed management}

Weed is a very big problem in our most of the field crops, chickpea is one of them. As per the density and type, weed it can reduce the yield upto $80 \%$ or more. Integrated Weed Management (IWM) is the main tool for controlling the weeds effectively. Ratnam et al., (2011) and Pandit et al., (2017) found the importance of IWM in control of weeds in chickea. It indicates from the Table 2 that 'Lack of knowledge about Integrated Weed Management' (88.50\%) followed by 'Lack of knowledge about importance of cultural, physical and chemical methods' $(78.50 \%)$ were the main reasons for Lack of Adoption of Integrated Weed Management. The other important constraints were 'lack of knowledge about weed identification' (56.00\%), 'unavailability of herbicide in time' $(34.50 \%)$, 'lack of knowledge about proper method of herbicide application' (29.50\%) and 'high cost of herbicide' (16.00\%).

\section{Problem of wilt disease}

It is found that wilt disease was one of the most important problems which causing yield reduction in gram crop. Seed treatment is very important solution for controlling the wilt disease. Seed treatment with chemical like bavistene protect the crop for 21 days while Trichoderma viridae protect the crop from wilt disease up to 38 to 40 days. There are so many reasons for less adoption of plant protection measures for controlling wilt disease. 'Lack of knowledge about different control methods' $(81.00 \%)$ followed by 'unavailability of resistant variety' (78.00\%) and 'lack of Crop Rotation Practice for disease control' (77.00\%) were the main reasons for the problem of wilt disease faced by farmers. Other important reasons were 'lack of Seed Treatment for disease control' $(66.50 \%)$, 'unavailability of chemicals' (46.50\%) and 'lack of knowledge about disease identification' (36.00).

\section{Problem of pod borer control}

Problem of pod borer infestation was also the very important factor responsible for gram yield reduction. Table 2 further reveals that 'lack of knowledge about selection of proper insecticide and its dose to control insect at different stages' $(89.00 \%)$ was the most important reason for the problem of pod borer experienced by the farmers. The other constraints experienced by less than 50.00 per cent respondents were 'unavailability of appropriate insecticide at right time ' $(42.50 \%)$, 'Lack of knowledge about insect attack' (39.50\%) and 'high cost of insecticide' (37.00\%).

\section{Lack of adoption of integrated pest management}

Integrated Pest management encompasses the right combination of different methods like cultural, physical, biological and chemical method of pest control. Choudhry et al., 2008 also advocated the importance of IPM in control of different insects. It is apparent from the data of Table 2 that 'Lack of knowledge about importance of IPM' (74.50\%) was the main reason for low adoption of Integrated Pest Management by the respondents.

'High cost of pesticide \& fungicides' (59.00\%) followed by 'unavailability of chemicals, plant protection equipments' $(45.50 \%)$ were the other important reasons reported by the farmers for the Lack of Adoption of Integrated Pest Management. 


\section{Seed losses during storage}

Every year thousands of tons, seed of different crops were lost due to insufficient storage facilities in our country. It is obvious from the Table 2 that major reason of seed losses during storage was 'lack of knowledge about importance of proper storage and its different methods' $(83.50 \%)$. Use of old jute bags for seed storage without cleaning, chemical treatment, sun drying and Lack of proper sun drying of seed (68\%) also responsible for seed losses during storage. Lack of proper storage facility $(58.50 \%)$, unavailability of fumigants $(55.00 \%)$ and use of traditional storage practices $(36.50 \%)$ were the other important reasons for seed losses during storage.

\section{References}

Anonymous, 2016. Agricultural statistics at a glance. Government of India Ministry of Agriculture \& Farmers Welfare Department of Agriculture, Cooperation \& Farmers Welfare Directorate of Economics and Statistics.

Chormule, S. R., V. J. Bhatiya and Patil, A.S. 2015. Effect of seed treatments on quality of chickpea. AGRES- An International eJournal. 4(1): 65-71.

Choudhry, R. G., H., Saxena, V., Dhar and Prajapati, R.K., 2008. Evaluation and validation of IPM Modules against wilt, phytophthora blight, pod borer and pod fly in pigeonpea. Journal of Food Legumes. 21: 58-60.

Dixon, J., L., Nalley, P., Kosina, R., La. Rovere, J., Hellin and Aquino, P. 2006. Adoption and economic impact of improved wheat varieties in the developing world. Journal of Agricultural Sciences. 144 (6): 489-502.

Feder, G., R. E., Just and Zilberman, D. 1985. Adoption of agricultural innovations in developing countries. Economic Development \& Cultural Change. 33 (2): 255-298.

Pandit, S., D.H., Rathod and Dodamani, B.M. 2017. Integrated weed management in chickpea (Cicer arietinum L.) under rainfed conditions of Karnataka, India. Legume Research. 40(3): 580-585.

Ratnam, M., A.S. Rao and Reddy, T.Y. 2011. Integrated weed management in chickpea (Cicer arietinum L.). Indian Journal of Weed Science. 43 (1\&2): 70-72.

Sanchez, P.A., G.L., Denning and Nziguheba, G. 2009. The African green revolution moves forward. Food Security. 1: 37-44.

Shahid, Mohd., Anuradha, Singh, Mukesh, Srivastava, C. P. Sachan and Biswas, S.K. 2011. Effect of seed treatment on germination and vigour in chickpea. Trends in Biosciences. 4(2): 205-207.

Singh, R.P.; D., Singh, A.P., Dwivedi and Singh, M. 2014. Adoption level of integrated pest management technology in Chick pea. Journal of Food Legumes. 27(2): 170-173.

Wanyama, J.M., E.M., Nyambati, L. O., Mose, C. M., Mutoko, W. M. Wanyonyi, E. Wanjekeche and Rono, S.C. 2010. Assessing impact of soil management technologies on smallholder farmers' livelihoods in North Western Kenya. African Journal of Agricultural Research. 5(21): 2899-2908.

\section{How to cite this article:}

Vikas Gupta, S.K. Mishra, R.K. Saraf and Akhilesh Tiwari. 2019. Gap in Adoption of Improved Production Technology of Gram among the Farmers of Rehli Block of Bundelkhand Region. Int.J.Curr.Microbiol.App.Sci. 8(07): 1494-1499. doi: https://doi.org/10.20546/ijcmas.2019.807.177 